\title{
Analysis of Global Stock Exchange Index, Foreign Exchange Rate, Interest Rate and Inflation Rate Influences CSPI in Indonesia Stock Exchange (Period of January $2014-2015$ )
}

\author{
Dahlia Br. Pinem
}

\begin{abstract}
The economy of one country with other countries are interconnected because of the business relationship, especially since the developed countries greatly affect the economy of developing countries, so that the stock market in developed countries such as Dow Jones (DJIA) index, Footsie London Index (FTSE), Singapore Index (STI), Tokyo Nikkei Index (N225), Korea KOSPI Index (KS11), Hang Seng Hongkong Index (HSI) affect the Composite Stock Price Index (CSPI). The purpose of this study is to determine the influence of global stock indices on the Composite Stock Price Index (CSPI). In addition to the global macroeconomic index of Indonesia's Stock Index like the US Dollar against the rupiah, interest rates greatly affect the Composite Stock Price Index. The method of the sample research was conducted by judgment sampling. Hypothesis testing in this research is conducted by Multiple Regression. The results obtained simultaneously (F test) variables (FTSE, Dow Jones index, STI, KS 11, Hangseng, Nikkei 225, Dollar/USD exchange rate, interest rate, Inflation) have a significant effect on CSPI. Yet, only partially variable interest rate is not significant, while the other partially affects the CSPI.
\end{abstract}

Index Terms: CSPI, Global Stock, Macro Economics.

\section{INTRODUCTION}

The world economics has entered an era of globalization where the relations of a country's economics are interdependent with each other. One of the causes of this dependency is the development of financial investment in various countries. The existence of international diversification has led to modern portfolio theory regarding the integration and interdependence of capital markets in various countries. One of the indicators that apply to the IDX is the Movement of CSPI is influenced by various factors both internal and external. External influences such as interest rate movement and foreign stock index are believed to have become the dominant factor affecting CSPI. As stated by Blanchard (2006), the factors that influence stock prices are interest rates, the state of the global economy, the level of world energy prices, political stability, etc. Meanwhile, internal factors are more influenced by domestic events such as rational expectations of investors and the influence of other macroeconomic

Published on December 24, 2019.

Dahlia Br. Pinem is a Lecturer at the Faculty of Economics and Business, Universitas Pembangunan Nasional "Veteran" Jakarta, Indonesia. (e-mail: pinem_dahlia@yahoo.com). variables such as the exchange rate of the rupiah against the US dollar, interest rates (Deposite Rate), inflation rate (Dedy Pratikno, 2009). Indonesian Institute of Accountants (Ikatan Akuntan Indonesia, IAI) in PSAK no.31 (2007), the middle exchange rate is the selling rate plus the buying rate of Bank Indonesia divided by two. Inflation is a state in which there is an excess demand for goods in the economy as a whole. Inflation as a continuous price increase of goods and services in general (not just one kind of goods and a moment). At the time the Dow Jones Index on the US stock exchange has decreased and has given a negative signal to investors in IDX, so the CSPI has decreased. One of the indices contained in the UK Capital Market is the Financial Times Stock Exchange 100 Index, commonly abbreviated as FTSE 100. As a developed country, the economy of the UK tends to have an impact on developing economies, one of which is Indonesia.

The Straits Times Index is a reflection of the economy in Singapore. The existence of the AFTA agreement for the entire Southeast Asia region has an impact on the Indonesian capital market which has been affected by the capital market in Singapore since Singapore investors can invest their funds in Indonesia.

The effects of the relations of the economy of Indonesia with other countries have made the Indonesian capital market integrated. The decline in the index of developed countries that have relations of the economy with Indonesia can give a negative signal to investors in Indonesia since foreign investors who performed international diversification in Indonesia make withdrawals of their shares to reduce risk due to changes in the market situation. This proves that the capital markets of the developed countries have influenced the capital market of Indonesia which is included as a country with a developing economy.

The Composite Stock Price Index (CSPI) is the weighted average of all shares listed on the IDX to provide convenience in measuring portfolio performance. The ups and downs of the stock price index depend on the economic conditions in a country. Indonesia uses the Composite Stock Price Index (CSPI) to reflect the development of the capital market of Indonesia. The advantage in investing can be obtained from the company's capital gains and dividends (Tandelilin, 2010). The Dow Jones Index (DJI) is a jointstock to measure the performance of industrial companies in the capital market of the US. As a superpower country, the US economy has the biggest influence on economies around the world, especially in Indonesia. 


\section{LITERATURE REVIEW}

1. Composite Stock Price Index (CSPI) (Mohamad Samsul, 2006) is a composite index of all types of shares listed on the stock exchange. Composite Stock Price Index (CSPI) is published by the stock exchange. The Composite Stock Price Index (CSPI) (Sunariyah) is a series of historical information about the movement of the combined stock price of all shares until a certain date.

2. The Dow Jones Index (Prakarsa \& Kusuma, 2008), is one of the stock market indices founded by the editor of The Wall Street Journal and founder of the Dow Jones \& Company, Charles Dow. Dow Jones Index is the oldest market index in the United States that is still running The Dow Jones Index currently consists of the 30 largest companies in the United States that are already widely publicly traded. Companies listed on the Dow Jones Index are large companies that have operated globally.

3. The FTSE 100 index (The Financial Times Stock Exchange) is a stock market index on the London stock exchange. This index is owned by several components of the FTSE, which was originally a joint venture of the Financial Times and the London Stock Exchange. The FTSE Group is a world leader in the establishment and management of more than 120,000 shares, bonds, and alternative asset class index. The FTSE index consists of the 100 highest chip companies capitalized in blue, representing around $81 \%$ of the UK market.

4. Strait Times Index (STI) is a weighted market value of the stock market index based on the shares of 30 representative companies listed on the Singapore stock exchange.

5. The Nikkei 225 index is a capital market index for the Tokyo Stock Exchange (TSE). The Nikkei is the most observed index of the Asian stock exchange.

6. Korean Kospi Index is the main index of South Korea which consists of 200 of the most Liquid major shares traded by the Korean Stock Exchange.

7. Exchange Rate is a comparison of the value or price of two currencies. Understanding the exchange rate of currencies according to the FASB is the ratio between a unit of currency with some other currencies that can be exchanged at a certain time. According to Nopirin (1990), the exchange rate is a kind of price in the exchange.

8. Interest rate. Changes in interest rates will have an impact on changes in the amount of investment in a country, both originating from domestic investors and foreign investors, especially in the type of portfolio investments that are generally short-term. Changes in interest rates will affect changes in the amount of demand and supply on the domestic money market.

9. Inflation, in general, is too much money in circulation which causes the prices of goods to rise generally in a relatively long period.

\section{RESEARCH METHODOLOGY}

Research Variables and Definition of Variable Operational

\section{Dependent Variable}

The dependent variable in this research is the CSPI. CSPI is a composite share price index issued by the Indonesia Stock Exchange every day. CSPI data is obtained directly at www.finance.yahoo.com. The data used are daily data during the observation period between 2014-2015

\section{Independent Variable}

The following are the independent variables used in this study, they are:

1. Dow Jones Index (X1)

The Dow Jones Index consists of 30 large and leading companies in the United States. The data used in this study were obtained at www.finance.yahoo.com.

2. Footsie London Index (X2)

The FTSE Index is owned by the London Stock Exchange, which is a collection of FTSE which was originally a joint venture between the Financial Times and the London Stock Exchange.

3. Singapore Index (X3)

STI Index (Strait Times Index) is the weighted market value of the stock market index based on the shares of 30 representative companies listed on the Singapore Stock Exchange.

4. Nikkei Index (X4)

The Nikkei 225 index is an index that can be used to measure the performance of large Japanese companies that operate globally.

5. Korean Kospi Index (X5)

The Korean Kospi Index (KSII) is an index in South Korea which consists of the 200 most liquid major stocks that are traded by Korea Stock Exchange.

6. Hang Seng Index (HSI) Hong Kong Stock Index

7. Exchange Rates (X7)

The exchange rate used is the exchange rate of Rupiah against the US Dollar at Bank Indonesia periodically

8. Interest Rate (X8)

The SBI interest rate is the interest rate issued by Bank Indonesia.

9. Inflation ( X9)

The level of price increase generally occurs continuously. The inflation rate used is the inflation rate obtained from the Consumer Price Index (Devianto, 2013).

\section{The Determination of Population and Sample}

\section{Population :}

The populations used in this study are all CSPI, DJIA, FTSE, STI, N225, KS11, HSI, Exchange Rate of Dollar against Rupiah, Interest rate and inflation rate data. Based on data available on the internet for all variables used in this research, data are available from 2014-2015.

The samples in this research are CSPI, DJIA, FTSE, STI, N225, KS11, HSI, Exchange Rate of Dollar against Rupiah, Interest rate and inflation rate data that are limited to daily closing data during the observation period between 20142015 based on daily data.

\section{Type and Source of Data}


The data used in this study are secondary ones in the form of CSPI, DJIA, FTSE, STI, N225, KS11, HSI, Exchange Rate of Dollar against Rupiah, Interest rate and inflation rate data during January to December 2014-2015 based on daily data. Secondary data is data in a ready-made form, which is a publication data.

\section{Data Collection Method}

Data in this study were collected through documentation from various sources. CSPI data collection was carried out in the IDX corner. Besides, data and information collection is conducted by taking from the internet, articles, journals, and studying from library books that support this research process.

\section{Analysis Method}

This research uses quantitative methods with multiple regression analysis tools. Multiple regression analysis was used to examine the effect of DJIA, FTSE, STI, N225, KS11, HSI, Exchange Rate, Interest rates and inflation rates on the CSPI. How much the independent variable influences the dependent variable is calculated using the following multiple regression line equation:

$\mathrm{Y}=\mathrm{a}+\mathrm{b} 1 \mathrm{X} 1+\mathrm{b} 2 \mathrm{X} 2+\mathrm{b} 3 \mathrm{X} 3+\mathrm{b} 4 \mathrm{X} 4+\mathrm{b} 5 \mathrm{X} 5+\mathrm{b} 6 \mathrm{X} 6+$ b7X7+b8X8+b9X9+e

\section{RESEARCH FINDINGS AND DISCUSSIONS}

\section{Descriptive Statistics}

\begin{tabular}{lrrrrr}
\hline \multicolumn{7}{c}{ TABLE 1: DESCRIPTIVE STATISTICS } \\
& $\mathrm{N}$ & \multicolumn{1}{c}{ Min } & \multicolumn{1}{c}{ Max } & Mean & \multicolumn{1}{c}{ Std. } \\
& & & & & Dev \\
IHSG & 489 & 4121 & 5523 & 4908 & 342 \\
FTSE & 489 & 5899 & 7104 & 6653 & 244 \\
Dowjones & 489 & 15373 & 18312 & 17173 & 693 \\
STI & 489 & 2788 & 3540 & 3229 & 177 \\
Ks 11 & 489 & 1830 & 2173 & 1997 & 60 \\
Hangseng & 489 & 20557 & 28443 & 23783 & 1714 \\
Nikkei 225 & 489 & 13910 & 20868 & 17335 & 2140 \\
Exchange & 489 & 9639 & 11462 & 10437 & 398 \\
Rate & & & & & \\
Interest & 489 & .0750 & .0775 & .07525 & .000 \\
& & & & & 717 \\
Inflation & 489 & .0335 & .6960 & .09084 & .129 \\
& & & & & 009 \\
Valid N & 489 & & & & \\
(Listwise) & & & & & \\
\hline
\end{tabular}

In table 1, it can be seen that the amount of data used in this research was 489 data. The average value of the Composite Stock Index (CSPI) was 4908, the FTSE stock index was 6653, the DOW_JONES Stock index was 17173, STI was 3229, KS11 was 1997, HANGSENG was 23783; NIKKEI_225 was 17335 , the exchange rate of $\mathrm{Rp} / \mathrm{S}$ of 10437; INTEREST was 0.07725, Inflation Rate was 0.09084 . The highest average index value is owned by Hangseng by 23783 and the lowest KS 11 index was 1997.

\section{Classical Assumption Test}

This research has passed the classical assumption test, namely: Normality Test, Auto Correlation Test, Multicollinearity Test and Heterokedacity Test.

\section{Hypothesis Testing}

1. T-test

TABLE 2: COEFFICIENTS ${ }^{\mathrm{a}}$

\begin{tabular}{lrl}
\hline Model & \multicolumn{1}{l}{$\mathrm{t}$} & Sig. \\
& & \\
1 (Constant) & 1.567 & .118 \\
FTSE & -10.041 & .000 \\
DOWJONES & 9.343 & .000 \\
STI & 18.357 & .000 \\
KS11 & 2.955 & .003 \\
Hangseng Hongkong & 1.983 & .048 \\
Nikei225 & -11.899 & .000 \\
Nilaitukar & -8.587 & .000 \\
Sukubunga & .716 & .474 \\
Inflasi & -2.546 & .011
\end{tabular}

Based on the calculation above, the FTSE, Dow Jones, STI, KS11, Hangseng, Nikkei 225 Stock Indices, Exchange Rates of Rupiah against $\$$ and Inflation Rate affect CSPI. Meanwhile, interest rates do not affect the CSPI. If seen from the above, then the stock index from external factors greatly affects the price of the joint-stock on the Indonesia Stock Exchange.

\section{F-test}

TABLE 3: ANOVA $^{\mathrm{a}}$

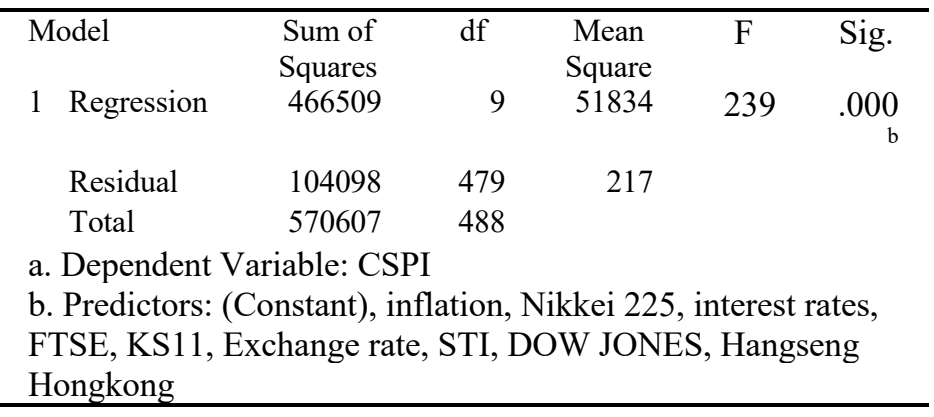

From the table above, it can be seen that $\mathrm{F}_{\text {count }}$ value is 239 with the significance rate of $0.000<0.05$. It can be concluded that together, all independent variables have a significant influence on the Composite Stock Price Index.

\section{Coefficient of Determination} TABLE 4: MODEL SUMMARY

\begin{tabular}{llrr} 
Mode & $\mathrm{R}$ & $\mathrm{R}$ Square & Adjusted R Square \\
1 & $.904^{\mathrm{a}}$ & .818 & .814 \\
\hline
\end{tabular}

The coefficient of determination is 0.814 or $81.4 \%$, this figure means that the CSPI can be explained by DJ, HSNT, FTSE, Interest Rates, KS 11, Nikkei, Inflation of 81.4, while the remaining $19.6 \%$ is influenced or explained by other variables which are not included in this research model.

\section{Multiple Regression Model}

TABLE 5: COEFFICIENTS ${ }^{a}$

Model $\quad$ Unstandardized




\begin{tabular}{lrr}
\hline & \multicolumn{2}{c}{ Coefficients } \\
(Constant) & 1314.759 & Std. Error \\
FTSE & -.493 & 838.877 \\
DOWJONES & .211 & .049 \\
STI & 1.783 & .023 \\
KS11 & .581 & .197 \\
Hangseng & .021 & .011 \\
Hongkong & & \\
Nikkei 225 & -.111 & .009 \\
Exchange rate & -.262 & .030 \\
Interest rate & 0.699 & 9327.281 \\
Inflation & -0.163 .425 & 64.180 \\
a. Dependent Variable: CSPI & \\
\hline \multicolumn{3}{r}{}
\end{tabular}

CSPI $=1314.759-0.493$ FTSE +0.211 Dow Jones + 1.783 STI $+0.581 \mathrm{KS} 11+0.021$ Hangseng -0.021 Nikkei $22 \mathrm{i}-0.262$ Exchange rate +0.6 interest rate 0.0163 Inflation

Discussions :

If seen from the statistics above, London Footsie Stock Index, Dow Jones Index, Singapore Index, Korean Kospi Index, Hangseng Hong Kong, Nikkei Japan affect CSPI in Indonesia. This shows if the price of the country's shares changes, it can be predicted that the CSPI will also experience changes. Yet, the Stock Price Index in the London Footsie and Nikkei 225 Japan is inversely proportional to the CSPI in Indonesia. Likewise, the exchange rate of $\mathrm{Rp} / \mathrm{S}$ and the inflation rate also have a significant, negative relationship. This indicates that if inflation and the exchange rate of $\mathrm{Rp} / \mathrm{\$}$ increase, the CSPI will decrease. The interest rate does not influence the Composite Stock Price Index in which the significance (siq $0.474>0.05)$

\section{CONCLUSIONS}

Based on the results of the analysis and discussion described, it can be concluded as follows:

The Independent Variable consists of:

1. FTSE, Exchange Rate of USD/Rp, interest rates. Dow Jones, STI, KS 11, Hang Seng, Inflation affect CSPI. Meanwhile, the Interest Rate does not affect the CSPI.

2. Simultaneously, it shows that there is a significant influence between FTSE, Dow Jones, STI, KS 11, Hangseng, Nikkei 225 variables, Exchange Rate of USD/IDR, Interest Rate, Inflation with CSPI.

3. Coefficient of Determination Test (R2) seen from the Adjusted R Square value which shows that the influence of the independent variable on the dependent variable is $81.4 \%$ and the rest is influenced by other factors by $19.6 \%$.

\section{REFERENCES}

Andiyasa, A. 2014. The influence of several stock indices and global economic indicators on the condition of the Indonesian capital market. Postgraduate Thesis, Udayana University.

Bank Indonesia. 2007-2011. Indonesian Financial Economics Statistics. Several editions of publication.

Ghozali, I. 2014. Structural Equation Modeling: Alternative Methods With Partial Least Square (PLS). Semarang: UNDIP

Jose Rizal Joesoef. 2007. Money Market and Foreign Exchange Market. Jakarta: Salemba Empat.

Pratikno, Dedy. 2009. Analysis of Influence of Rupiah Exchange Rate, Inflation, SBI, and Dow Jones Index on JCI Movement on the Indonesia Stock Exchange . Thesis. North University of Sumatera. Medan.

Sunariyah. 2006. Introduction to Capital Market Knowledge, Fifth Edition. Yogyakarta: UPP STIM YKPN

Samsul, Mohammad. 2008. Capital Markets and Portfolio Management. Jakarta: Erlangga.

Sakthivel, P., Bodkhe, N., and Kamaiah, B. 2012. Correlation and volatility transmission across International Stock Markets: A bivariate GARCH analysis. International Journal of Economics and Finance, 4 (3): 253-264.

Shevanda, F. T. 2013. Influence Dow Jones Industrial Average, Deutscher Aktienindex, Shanghai.

Stock Exchange Composite Index, and Straits Times Index on the Composite Stock Price Index on the Indonesia Stock Exchange (Period 2010 - 2012). Faculty of Economics and Business, Brawijaya University. Malang.

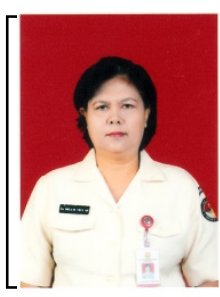

Dahlia Br. Pinem is a lecturer of management in Faculty of Economics and Business at Universitas Pembangunan Nasional "Veteran" Jakarta, Indonesia. She holds a Masters of Management from Jagakarsa University, Indonesia. Her current research interest are in areas of Finance, Macro Economics and Entrepreneur. She has published a number of papers in various refereed journal and conference proceedings. 